\title{
SEX PROPORTION IN LEGBAR DAY-OLD CHICKS
}

\author{
HARALD EBBELL \\ Ovomaltine Eierfarm, Oberwanger b. Bern \\ Switzerland
}

Since the Japanese chick-sexing method is not yet used in Switzerland, the few sexed chicks we sell in our country have been first brown Leghorns, where we were able to give a guarantee of $90 \%$ for pullet-chicks, and now for the past two seasons Legbars, the well-known auto-sexing breed of Punnet and Pease from Cambridge University, where it is quite easy to get an 98-100\% accuracy in sex-determination. The breed certainly has economic possibilities in our country, where light breeds are preferred for egg production, but where also a lot of people-especially farmers-do not like a white hen as the Leghorn, but ask for a brown one. They like the Legbars, we like them too, but there has been one inconvenience of rather a serious character: there have been much more cockerel-chicks than pullet-chicks. We first noticed this in 1948. When estimating the number of pulletchicks to be disposed of, we calculated on a sex-proportion of about $50 \%$ pullet-chicks. But at hatching time we often had to cancel commands because of an excessive number of cockerel-chicks and therefore fewer pullet-chicks than calculated. We decided to collect exact figures on this sex-proportion in 1949 from our Legbar hatches. Here they are:

\section{STATISTIC AND GRAPH}

From the pen-mated-birds we got out 3177 day-old cockerels and 2455 day-old pullets, that is to say $56.4 \%$ cockerelchicks versus $43 . \%$ pullet-chicks. There have been rather astonishing variations between the figures of the different hatches, the relative figures ranging from $50.5 \%$ up to $65.1 \%$ cockerel-chicks. The first 4 hatches in February and March had the least cockerel chicks, but afterwards the graph does not show a clear influence of season on sex-proportion

Apart from the pen-mated-birds the statistic shows the figures of two pedigreed matings. Pen Nr. 8 had 363 cockerel-chicks versus 284 pullet-chicks, whilst Pen B had 147 cockerel-chicks versus 171 pullet-chicks, that is to say in Pen B there were more pullet-chicks than cockerel-chicks. The number of chicks of these two pedigreed matings-especially in Pen B-yet is too limited; the figures are not significant statistically. But the question arises, if there are differences 
1F2. 24. 3.3. 10. 16. 24. 31. F.4. 14. 21. 28. 5.5. 12. 19. 25.2 .6$.

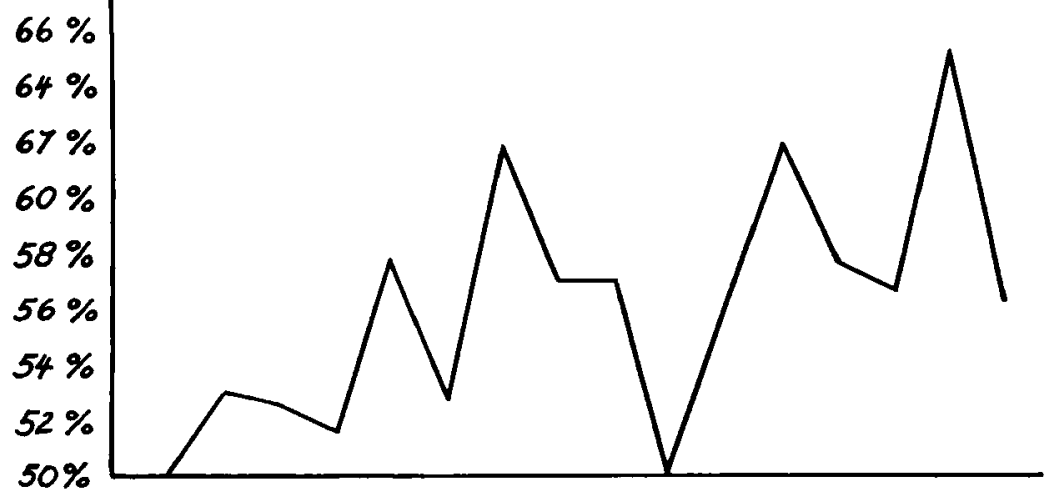

Influence of season on proportion of cockerel chicks

SEX PROPORTION IN LEGBAR DAY-OLD CHICKS

\begin{tabular}{|c|c|c|c|c|c|c|c|}
\hline \multirow{3}{*}{$\begin{array}{l}\text { Date of } \\
\text { Hatch }\end{array}$} & \multicolumn{3}{|c|}{ Pen mated birds } & \multicolumn{2}{|c|}{ Pedigreed matings } & & \\
\hline & \multirow{2}{*}{\multicolumn{2}{|c|}{$\begin{array}{c}\text { Cockerels } \\
\text { No. } \%\end{array}$}} & \multirow[b]{2}{*}{$\begin{array}{l}\text { Pullets } \\
\text { No. }\end{array}$} & \multicolumn{2}{|l|}{ B } & \multicolumn{2}{|c|}{8} \\
\hline & & & & Cockerels & Pullets & Cockerels & Pullets \\
\hline 17.2. & 100 & 50.5 & 98 & 1 & 5 & 4 & 3 \\
\hline 24.2 . & 130 & 53.0 & 115 & 4 & 9 & 6 & 5 \\
\hline 3.3. & 170 & 52.7 & 152 & 10 & 12 & 9 & 13 \\
\hline 10.3 & 155 & 51.7 & 145 & 5 & 19 & 13 & 13 \\
\hline 17.3. & 210 & 57.5 & 155 & 15 & 10 & 21 & 18 \\
\hline 24.3. & 213 & 52.8 & 190 & 13 & 7 & 28 & 21 \\
\hline 31.3. & 275 & 61.7 & 170 & 12 & 12 & 22 & 24 \\
\hline 7.4. & 266 & 57.0 & 200 & 13 & 10 & 28 & 22 \\
\hline 14.4 . & 265 & 57.0 & 200 & 9 & 14 & 26 & 24 \\
\hline 21.4 . & 211 & 50.5 & 206 & 15 & 8 & 29 & 27 \\
\hline 28.4 & 250 & 56.3 & 194 & 2 & 14 & 26 & 24 \\
\hline 5.5. & 250 & 61.8 & 154 & $\overline{1}$ & $\overline{11}$ & $\bar{\sigma}$ & $\overline{0}$ \\
\hline 12.5. & 175 & 57.7 & 128 & 14 & 14 & 35 & 30 \\
\hline 19.5 . & 225 & 56.8 & 171 & 10 & 16 & 47 & 15 \\
\hline 26.5 & 174 & 65.1 & 93 & 9 & 12 & 32 & 14 \\
\hline \multirow[t]{3}{*}{2.6 . } & 108 & 56.2 & 84 & 15 & 9 & 37 & 31 \\
\hline & 3,177 & & 2,455 & 147 & 171 & 363 & 284 \\
\hline & $56.4^{\circ}$ & & $43.6 \%$ & $46.2 \%$ & $53.8 \%$ & $56.1 \%$ & $43.9 \%$ \\
\hline
\end{tabular}

in sex-proportion in the offspring of different sires. The purpose of these lines is not and can not be more than an incitation to investigate the whole matter more deeply and on a larger scale. Unfortunately we were not able to collect figures from our Leghorn hatches, which are much larger than those of the Legbars, but I am quite sure that also with the Leghorns we had more cockerels than pullets this year.

There are some questions arising from the problem of 
sex-proportion, which need investigation on a large scale:

1) Are there climatical, seasonal, weather- or other conditions influencing sex-proportion?

2) Are there differences in the sex-proportion in the offspring of different sires?

3) Are there differences in the sex-proportion between different breeds?

Personally I would be very interested to get answers on a further question:

4) Are there other breeders of Legbars—or some different auto-sexing breed-having made the same experiences as we did on sex-proportion in day-old chicks?

\title{
BLOOD ANTIGENS
}

\author{
W. E. BRILES \\ Agricultural and Mechanical College of Texas, \\ College Station, Texas, U.S.A.
}

Detailed studies of the serological detection, genetic identification, and possible physiological effects of the red cell antigens offer promising possibilities in providing new tools for the breeder. Improving the breeding quality of our chickens and turkeys is slow and costly, and any information which might be utilized in increasing the efficiency of the breeding process would not only benefit the poultry breeders of Texas but those of the nation as well. Any correlation found between the antigenic constitution of a bird and its economic value would make for increased accuracy of selection, thus directly affecting the progress made in practical breeding operations.

Further investigation of the red cell antigens is very important to those interested in developing inbred lines of chickens. There is a need for some relatively simple method of confirming the pedigree of unusually vigorous individuals which appear occasionally in inbred lines. By determining the antigens possessed by the red cells of all of the possible parents along with those of the suspicious individual it could be determined in most cases whether or not the individual could actually have resulted from the mating indicated by the pedigree.

Present evidence strongly suggests that there may be a positive selective advantage for the heterozygous condition at 